\title{
Analysing the Route of PCI Girder-Type Prestressed Concrete Tendons
}

\author{
Cut Rahmawati ${ }^{1}$, Zainuddin ${ }^{2}$, Nosa Safwanda ${ }^{3}$, Syafridal $\mathbf{I s}^{4}$ \\ ${ }^{1,2,3,4}$ Abulyatama University, Departement of Civil Engineering, Jl. Blang Bintang Lama Km. 8,5, Aceh Besar, Indonesia
}

\begin{abstract}
This paper will analyse the middle span of the 31m-in-length bridge. The calculation stages undertaken here were to design the form and dimensions using PCI Girder-Type Prestressed Concrete, to determine the prestress force, eccentricity as well as the number of tendons and routes of each cable; and to calculate the resulting stress of the beam cross-section and the resulting loss of prestress forces. There were 4 tendons of prestressed cables for the PCI Girder design, each of which consisted of 19 high quality wires, i.e. uncoated 7 Wire Super Strands ASTM A-416 grade 270 with the cross-section equal to $12.7 \mathrm{~mm}$ in width and the ultimate tensile stress by1,860 Mpa, with a total of 76 strands. The tendon tensioning system implemented was the post-tensioning one where the prestress force was given when the concrete has already achieved the required age. The Bridge of Meureudu City experienced a total prestressed loss by $26.32 \%$. The tendon route was parabolic with the greatest moments by $7,556.75 \mathrm{kNm}$ derived from a combination of its own weight, additional dead loads, lane loads, the brake force and wind loads.
\end{abstract}

Keywords: Prestressed Concrete, PCI Girder, Tendons, Strands Cable

\section{Introduction}

Prestressed concrete is a material used very commonly in various constructions in Indonesia. The steel reinforcement of this type of concrete is pulled/ stressed towards its concrete. Among the advantages of using this prestressed concrete structure are that the beams are lighter, slimer and stiffer and that maximum savings can be made on long-span structures, as they are more economical than reinforced concrete and steel constructions. A bridge's capability and reliability is strongly influenced by the type and strength of the girders. Girders are a structural beam that directly receives the traffic load after the slab, which then distributes the load to the column and forwards it to the foundations. To assembly these girders, pillars are used to support them while diaphragms are used to provide reinforcement, diaphragms are a structural element whose function is to bind the girders so as to provide stability on each girder in the horizontal direction.

In this paper, the author used as an example the utilization of prestressed concrete in the Meureudue Bridge situated in Pidie Jaya Regency of Aceh. During its development, the traffic flow of Meureudu City as the capital of Pidie Jaya Regency has grown rapidly. Consequently, this Meureudu Bridge will be widened by the Highways Service of Aceh which is planned to reach 18.10 meters in width. The Construction of the Bridge of Meureudu City is planned to use prestressed concrete girders with with a PCI-type crosssection (Precast Concrete Type I).

In this case, the author will analyse the route of the tendons of the prestressed concrete girders using different concrete quality as planned by the planning consultant. The consultant planned to use K-600 prestressed concrete girders and K-350 vehicle floor plates. In this planning, the author used K-500 prestressed concrete girders and K-300 vehicle floor plates.

The prestressed steel tendons used were a type of high quality steel, in the forms of wire, strands and bars. For the planning, strands and cable strands used were those with VSL (Vorspam System Losinger) standards, namely uncoated 7 Wire Super Strands ASTM A-416 grade 270 with the cross-section equal to $12.7 \mathrm{~mm}$ in width and the ultimate tensile stress by1,860 Mpa. The tendon tensioning system implemented was the post-tensioning one where the prestress force was given when the concrete has already achieved the required age.

According to Lin, T.Y. (1993: 169) the estimated height of the prestressed concrete cross-section can be calculated using the formula: $\mathrm{h}=\mathrm{k} \sqrt{ } \mathrm{M}$ or it can also be calculated based on the function of the span length ( $\mathrm{L}$ ), $\mathrm{H}=1 / 14 \mathrm{~L}$ to $1 / 20 \mathrm{~L}$ (for heavy loads) and $H=1 / 20 \mathrm{~L}$ to $1 / 30 \mathrm{~L}$ (for light loads). The type of bearing used in the PCI girder design was the hingeroller bearing, where the structure analysis due to the loads on the beams was calculated based on RSNI T-02-2005 used to calculate the loads and forces working on the bridge.

\section{Material and Methods}

The calculation stages included designing the form and dimensions using PCI Girder-Type Prestressed Concrete; determining the effective width of both the plates and composite beams; analysing the cross-section which has the ability to resist bending due to forces on the prestressed beams, as a result of their own weight, additional dead loads, lane loads, the brake force, wind loads and earthquake loads; determining the prestress force, eccentricity as well as the number of tendons and routes of each cable; planning shear reinforcement, shear connectors and the end block to resist the prestressed tensile strength; and, lastly, calculating the resulting stress of the beam cross-section and the resulting loss of prestress forces.

The beam structure analysis was calculated based on RSNI T-02-2005 on "Loading for Bridges". To deter mine prestress forces and the loss of prestress forces, the formula proposed by T.Y. Lin was used. Cable strands and anchor use on the the Bridge of Meureudu City were from VSL products. 


\section{International Journal of Science and Research (IJSR) \\ ISSN (Online): 2319-7064 \\ Index Copernicus Value (2013): 6.14 | Impact Factor (2014): 5.611}

Prestressed girders used the post-tensioning method. In this method, the first step is to cast concrete with ducts or space for placing cables/ strands. If the concrete has been strong enough, then the cables/ strands are pulled and their ends are anchored, then the ducts are grouted.

This work of designing prestressed concrete beams was completed in several stages. In general, these stages are described as follows:

\section{Preparation Stage}

This stage began with doing library research, i.e. collecting relevant literature, references and regulations concerning loading for bridges and designing of PCI Girders.

\section{Data Collection Stage}

Data yang dibutuhkan adalah berupa:

The necessary data included:

a) Design drawings consistent with the planning made by the Highways Service of Aceh

b) Earthquake data retrieved from the Earthquake Map of Indonesia 2010

c) The applicable regulations, namely:

1) RSNI T-02-2005, used to calculate loads and forces on the bridge; and

2) SNI T-12-2004 concerning the Rules for the Concrete Structure for Bridges.

To design the prestressed concrete, several data need to be obtained previously on the field conditions and the planned quality of the concrete to be designed.

The existing data to analyse the planned basic calculations are presented as follows:

Middle span length

$: 31 \mathrm{~m}$

Beam cross-section height

$: 1.60 \mathrm{~m}$

Discance among ctc prestressed beams

$: 1.85 \mathrm{~m}$

Concrete plate thickness

Asphalt thickness

$: 0.2 \mathrm{~m}$

: $0.05 \mathrm{~m}$

Concrete quality

Plate concrete quality

: f'c $50 \mathrm{Mpa}$

: f'c $30 \mathrm{Mpa}$

In this research, the I-shaped prestressed concrete girder cross-section was used with a dimensional approach used was retrieved from WIKA's catalogue. Later, it was controlled against the width of the cross-section in accordance with the resulting maximum moment. If the width of the cross-section satisfied the conditions, then the calculation was continued at a later stage, but if it did not, then it had to be redesigned. Table 1 and Figure 1 presents the cross-section of I-shaped prestressed concrete girders.

Table 1: Code and width of prestressed beams (PCI girder)

\begin{tabular}{|c|c|c|c|}
\hline Code & $\begin{array}{c}\text { Width } \\
(\mathbf{m})\end{array}$ & Code & $\begin{array}{c}\text { Thickness } \\
(\mathbf{m})\end{array}$ \\
\hline b1 & 0,64 & h1 & 0,07 \\
\hline b2 & 0,8 & h2 & 0,13 \\
\hline b3 & 0,3 & h3 & 0,12 \\
\hline b4 & 0,2 & h4 & 1,15 \\
\hline b5 & 0,25 & h5 & 0,25 \\
\hline b6 & 0,7 & h6 & 0,25 \\
\hline \multicolumn{2}{r|}{} & h & $\mathbf{1 , 6 0}$ \\
\cline { 3 - 4 }
\end{tabular}

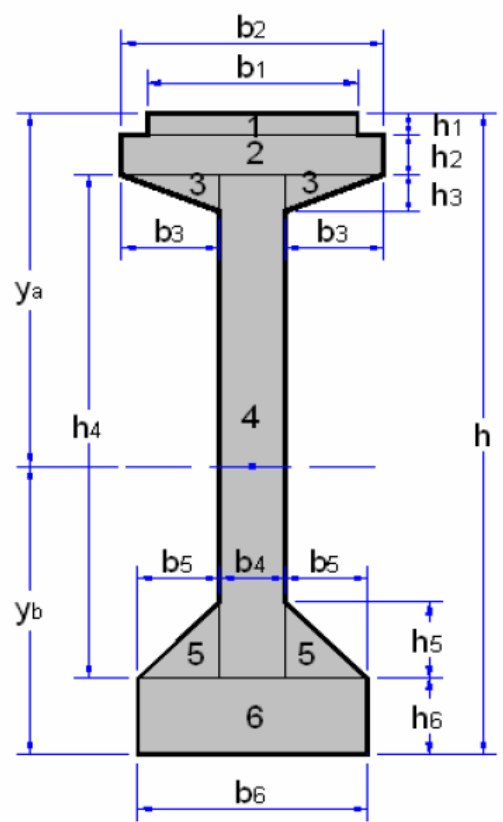

Figure 1 : Section Properties of Prestressed Beams (PCI girder)

Source: WIKA's Concrete Catalogue

\section{The Planned Quality of the Materials}

The construction of the Bridge of Meureudu City used K-500 prestressed concrete girders and $\mathrm{K}_{-300}$ vehicle floor plates. The prestressed steel tendons used were a type of high quality steel, in the forms of wire, strands and bars. For the planning, strands and cable strands used were those with VSL (Vorspam System Losinger) standards, namely uncoated 7 Wire Super Strands ASTM A-416 grade 270 with the cross-section equal to $12.7 \mathrm{~mm}$ in width and the ultimate tensile stress by1,860 Mpa. The tendon tensioning system implemented was the post-tensioning one where the prestress force was given when the concrete has already achieved the required age. The relationship between the girders and floor plates of vehicles was given a shear connector, so that the two construction components functioned in conjunction.

\section{Designs of Prestressed Beam Loading}

a) Calculating its own weight

b)Calculating additional dead loads

c) Calculating lane loads

d) Calculating the brake force

e) Calculating wind loads

f) Calculating earthquake loads

g)Calculating the moment, shear force and the combined loads on the beam

1) Calculations at the Stage of Loading on the Girders

a. Calculations at the transfer stage

b. Calculations at the service stage

2) Calculations of Prestressed Beam Ironworks

3) Calculations of Tendons' Central Position and Route

4) Calculations the Loss of the Prestress Force

a) The loss of stress due to friction along tendons

b) The loss of stress due to transportation

c) The loss of stress due to elastic shortening of concrete

d) The loss of stress due to steel creep (CR) 


\section{International Journal of Science and Research (IJSR) \\ ISSN (Online): 2319-7064 \\ Index Copernicus Value (2013): 6.14 | Impact Factor (2014): 5.611}

e) The loss of stress due to concrete shrinkage (SH)

f) The loss of stress due to steel relaxation (RE)

\section{5) Calculations of the Stress Control on the Beam Cross- Section}

Control of the resulting stress on the beam cross-section was analyzed based on the initial condition (transfer), the condition after the loss of prestress, the condition after plates had been completely casted (fresh concrete) and the condition after the beams turned into a composite.

\section{Results and Discussion}

\section{Section Properties of Girder}

From the result of girder cross-section designing, the width of the grider cross-section was obtained, namely $\left(A_{c}\right)=0.65230 \mathrm{~m}^{2}$. The details are presented in Table 2 .

Table 2 : Momen of inertia (PCI girder)

\begin{tabular}{|c|c|c|c|c|c|c|c|}
\hline \multirow{4}{*}{$\mathrm{No}$} & \multicolumn{2}{|c|}{ Dimensions } & \multirow{2}{*}{$\begin{array}{c}\text { Cross } \\
\text { Section } \\
\text { Area }\end{array}$} & \multirow{2}{*}{$\begin{array}{c}\text { Distance } \\
\text { to the } \\
\text { Base }\end{array}$} & \multirow{2}{*}{$\begin{array}{c}\text { Static } \\
\text { Moment }\end{array}$} & \multirow{2}{*}{$\begin{array}{l}\text { Moment } \\
\text { of } \\
\text { Inertia }\end{array}$} & \multirow{2}{*}{$\begin{array}{l}\text { Moment } \\
\text { of } \\
\text { Inertia }\end{array}$} \\
\hline & Width & Height & & & & & \\
\hline & $b$ & $h$ & $A$ & $y$ & $A^{*} y$ & $A^{*} y^{2}$ & Io \\
\hline & $(m)$ & (m) & $\left(m^{2}\right)$ & (m) & $\left(m^{3}\right)$ & $\left(m^{4}\right)$ & $\left(m^{4}\right)$ \\
\hline 1 & 0,64 & 0,07 & 0,04480 & 1,57 & 0,07011 & 0,10973 & 0,00002 \\
\hline 2 & 0,80 & 0,13 & 0,10400 & 1,47 & 0,15236 & 0,22321 & 0,00015 \\
\hline 3 & 0,30 & 0,12 & 0,03600 & 1,32 & 0,04752 & 0,06273 & 0,00004 \\
\hline 4 & 0,20 & 1,15 & 0,23000 & 0,83 & 0,18975 & 0,15654 & 0,02535 \\
\hline 5 & 0,25 & 0,25 & 0,06250 & 0,33 & 0,02083 & 0,00694 & 0,00033 \\
\hline 6 & 0,70 & 0,25 & 0,17500 & 0,13 & 0,02188 & 0,00273 & 0,00091 \\
\hline \multicolumn{3}{|c|}{$\Sigma$} & 0,65230 & & 0,50245 & 0,56188 & 0,02679 \\
\hline
\end{tabular}

\section{The Effective Width of Floor Plates}

The effective width of plates (Be) was taken from the smallest value from:

The effective width of floor plates was calculated Compressive strength of concrete plates Compressive strength of concrete beams

Elastic modulus of concrete plates

Elastic modulus of prestressed concrete beams

The comparison between the plate's elastic modulus value and the beam's elastic modulus value

Therefore, the replacement width of the bridge's concrete floor plates

To cope with any obstacles and difficulties during transport, the prestressed beams made were made in a segmental form where the maximum weight of each segment was equal to 80 $\mathrm{kN}$ so that they could be carried by a truck with a capacity of $80 \mathrm{kN}$, then the beam segments were adjoined in the bridge location.

\section{Designs of Prestressed Beam Loading}

Loads acting on the prestressed concrete bridge beams were comprised of dead loads and live loads, multiplied by the impact coefficient. These loads resulted in a moment which affected the strength on the prestressed concrete girders.

\section{Dead Loads}

Dead loads consisted of the weight of prestressed beams themselves, floor plates, dect slab and diaphragm. As for the additional dead loads, they consisted of the weight of asphalt

layers + overlay and rain water. The weight of prestressed beams was equal to $16.308 \mathrm{kN}$, the weight of floor plates was equal to $9.250 \mathrm{kN}$, the weight of dect slab was equal to 2.118 $\mathrm{kN} / \mathrm{m}$, the weight of the diaphragm was equal to 128.081 $\mathrm{kN}$, the weight of the asphalt layer + overlay was equal to $2.035 \mathrm{kN}$ and the weight of rain water was equal to $0.453 \mathrm{kN}$.

\section{Live Loads}

Live loads consisted of lane loads, the brake force, wind loads and earthquake loads. In relation to the lane loads, it consisted of loads which were evenly distributed on the beams, line loads and loads concentrated on the beam. The weight of evenly distributed lane loads amounted to 8.855 $\mathrm{kPa}$, the weight of line loads amounted to $16.381 \mathrm{kN} / \mathrm{m}$, the weight of concentrated loads amounted to $113.960 \mathrm{kN}$, the height of the brake force a beam received amounted to 50 $\mathrm{kN}$, the weight of the wind force amounted to $1.008 \mathrm{kN} / \mathrm{m}$ and the weight of the earthquake loads amounted to 3.5984 $\mathrm{kN} / \mathrm{m}$.

\section{Calculation of the Moment, Shear Force and the Combined Loads on the Beams}

Based on the forces working on the bridge girders, they would generate the maximum moment and the shear force on girders, which would determine the combination of loads on the forces working on the girders. For the calculations of the moment and shear force of the beams as a result of their own weight and additional dead loads, they can be seen in the 


\section{International Journal of Science and Research (IJSR) \\ ISSN (Online): 2319-7064 \\ Index Copernicus Value (2013): 6.14 | Impact Factor (2014): 5.611}

following Table 3. Table 4 presents the calculations of beams' There are 4 (four) moment combinations for the beam loading with moment and shear force as a result of additional dead loads. the resulting combination values as shown in Table 5.

Table 3 : The calculations of beams' moment and shear force as a result of their own weight

\begin{tabular}{|c|c|c|c|c|c|c|c|c|}
\hline No & Type of Load Weight & $\begin{array}{c}\text { Width } \\
\mathbf{b} \\
\mathbf{( m )}\end{array}$ & $\begin{array}{c}\text { Thickness } \\
\mathbf{h} \\
\mathbf{( m )}\end{array}$ & $\begin{array}{c}\text { Area } \\
\mathbf{A} \\
(\mathbf{m} 2)\end{array}$ & $\begin{array}{c}\text { weight per unit } \\
\mathbf{w} \\
\mathbf{( k N / \mathbf { m } )}\end{array}$ & $\begin{array}{c}\text { Load } \\
\mathbf{Q M S} \\
\mathbf{( k N})\end{array}$ & $\begin{array}{c}\text { Shear } \\
\mathbf{Q M S} \\
\mathbf{( k N})\end{array}$ & $\begin{array}{c}\text { Moment } \\
\mathbf{M M s} \\
\mathbf{( k N / \mathbf { m } )}\end{array}$ \\
\hline 1 & Prestressed Beam & & & & & 16.308 & 252.766 & $1,958.938$ \\
\hline 2 & Floor Plate & 1.850 & 0.200 & 0.370 & 25.000 & 9.250 & 143.375 & $1,111.156$ \\
\hline 3 & Deck Slab & 1.250 & 0.070 & 0.088 & 25.000 & 2.188 & 33.906 & 262.773 \\
\hline 4 & Diaphragm & & & & & 7.345 & 113.850 & 882.338 \\
\hline & & & & & Total & 35.090 & 543.898 & $4,215.206$ \\
\hline
\end{tabular}

Table 4 :The calculations of beams' moment and shear force as a result of additional dead loads

\begin{tabular}{|c|c|c|c|c|c|c|c|c|}
\hline No & $\begin{array}{c}\text { Type of Load } \\
\text { Weight }\end{array}$ & $\begin{array}{c}\text { Width } \\
\mathbf{b} \\
\mathbf{( m )}\end{array}$ & $\begin{array}{c}\text { Thickness } \\
\mathbf{h} \\
\mathbf{( m )}\end{array}$ & $\begin{array}{c}\text { Area } \\
\mathbf{A} \\
\mathbf{( m 2 )}\end{array}$ & $\begin{array}{c}\text { weight per unit } \\
\mathbf{w} \\
\mathbf{( k N} / \mathbf{m})\end{array}$ & $\begin{array}{c}\text { Load } \\
\mathbf{Q M A} \\
\mathbf{( k N})\end{array}$ & $\begin{array}{c}\text { Shear } \\
\text { VMA } \\
\mathbf{( k N})\end{array}$ & $\begin{array}{c}\text { Moment } \\
\mathbf{\mathbf { M } _ { \text { MA } }} \\
\mathbf{( k N / \mathbf { m } )}\end{array}$ \\
\hline 1 & $\begin{array}{c}\text { Asphalt Layer }+ \\
\text { Overlay }\end{array}$ & 1.850 & 0.050 & 0.093 & 22.000 & 2.035 & 31.543 & 244.454 \\
\hline 2 & Rain Water & 1.850 & 0.025 & 0.046 & 9.800 & 0.453 & 7.025 & 54.447 \\
\hline & & & & & Total & 2.488 & 38.568 & 298.901 \\
\hline
\end{tabular}

Table 5 : The calculations of moments and load combinations of beams

\begin{tabular}{|c|c|c|c|c|c|c|c|c|c|c|c|}
\hline \multirow{3}{*}{$\begin{array}{c}\text { Distance } \\
\mathbf{X}\end{array}$} & \multicolumn{7}{|c|}{ Moment of the prestressed beams as result of loads } & \multirow{3}{*}{$\begin{array}{c}\mathrm{COMIB} I \\
\mathrm{MS}+\mathrm{MA}+ \\
\mathrm{ID}+\mathrm{IB}\end{array}$} & \multirow{3}{*}{$\begin{array}{c}\text { COMIB II } \\
\mathrm{MS}+\mathrm{M} A+ \\
\mathrm{ID}+\mathrm{EW}\end{array}$} & \multirow{3}{*}{\begin{tabular}{|c|}
$\mathrm{COM} B \mathrm{BI}$ \\
$\mathrm{MS}+\mathrm{ML}+$ \\
\end{tabular}} & \multirow{3}{*}{$\begin{array}{c}\text { COMIB IV } \\
\text { MS+MLA } \\
\text { EQ }\end{array}$} \\
\hline & \multirow{2}{*}{$\begin{array}{l}\text { Theigh of } \\
\text { Beam }\end{array}$} & Own Weight & AdditioualDead Loads & Lane Loads " $\mathrm{D} "$ & Brake Force & WindLoads & Earthquake Loads & & & & \\
\hline & & MIS & MIA & ID & IB & ETV & EQ & & & & \\
\hline $\mathrm{m}$ & $\mathrm{kNm}$ & $\mathrm{kNm}$ & $\mathrm{kNm}$ & $\mathrm{kNm}$ & $\mathrm{kNm}$ & $\mathrm{kNm}$ & $\mathrm{kNm}$ & $\mathrm{kNm}$ & $\mathrm{kNm}$ & \begin{tabular}{|l|}
$\mathrm{kNm}$ \\
\end{tabular} & $\mathrm{kNm}$ \\
\hline 0,000 & 0,0 & 0,0 & 0,0 & 0,0 & 0,0 & 0,0 & 0,0 & 0,0 & 0,0 & 0 & 0 \\
\hline 0,775 & 191,00 & 410,98 & 29,14 & 236,02 & 3,53 & 11,81 & 44,01 & 679,7 & 687,95 & 691,48 & 484,14 \\
\hline 1,550 & 372,20 & 800,89 & 56,79 & 462,21 & 7,05 & 23,01 & 85,77 & 1326,9 & 1342,89 & 1349,95 & 943,45 \\
\hline 2,325 & 543,61 & 1169,72 & 82,95 & 678,55 & 10,58 & 33,60 & 125,27 & 1941,8 & 1964,82 & 1975,40 & 1377,93 \\
\hline 3,100 & 705,22 & 1517,47 & 107,60 & 885,05 & 14,11 & 43,59 & 162,51 & 2524,2 & 2553,72 & 2567,83 & 1787,59 \\
\hline 3,875 & 857,04 & 1844,15 & 130,77 & 1081,72 & 17,64 & 52,98 & 197,49 & 3074,3 & 3109,62 & 3127,25 & 2172,41 \\
\hline 4,650 & 999,06 & 2149,75 & 152,44 & 1268,55 & 21,16 & 61,75 & 230,22 & 3591,9 & 3632,49 & 3653,66 & 2532,41 \\
\hline 5,425 & 1131,29 & 2434,28 & 172,62 & 1445,53 & 24,69 & 69,93 & 260,69 & 4077,1 & 4122,36 & 4147,05 & 2867,59 \\
\hline 6,200 & 1253,72 & 2697,73 & 191,30 & 1612,68 & 28,22 & 77,50 & 288,90 & 4529,9 & 4579,21 & 4607,42 & 3177,93 \\
\hline 6,975 & 1366,36 & 2940,11 & 208,48 & 1769,99 & 31,74 & 84,46 & 314,86 & 4950,3 & 5003,04 & 5034,78 & 3466,45 \\
\hline 7,750 & 1469,20 & 3161,40 & 224,18 & 1917,46 & 35,27 & 90,81 & 338,56 & 5338,3 & 5393,86 & 5429,13 & 3724,14 \\
\hline 8,525 & 1562,25 & 3361,69 & 238,37 & 2055,09 & 38,80 & 96,57 & 360,00 & 5693,9 & 5751,66 & 5790,46 & 3960,00 \\
\hline 9,300 & 1645,51 & 3540,77 & 251,08 & 2182,88 & 42,33 & 101,71 & 379,18 & 6017,1 & 6076,45 & 6118,77 & 4171,03 \\
\hline 10,075 & 1718,97 & 3698,84 & 262,29 & 2300,84 & 45,85 & 106,25 & 396,11 & 6307,8 & 6368,22 & 6414,07 & 4357,24 \\
\hline 10,850 & 1782,63 & 3835,84 & 272,00 & 2408,95 & 49,38 & 110,19 & 410,78 & 6566,2 & 6626,98 & 6676,36 & 4518,62 \\
\hline 11,625 & 1836,50 & 3951,76 & 280,22 & 2507,23 & 5291 & 113,52 & 423,20 & 67921 & 6852,72 & 6905,62 & 4655,17 \\
\hline 12,400 & 1880,58 & 4046,60 & 286,94 & 2595,66 & 56,43 & 116,24 & 433,35 & 6985,6 & 7045,45 & 7101,88 & 4766,90 \\
\hline 13,175 & 1914,86 & 4120,36 & 292,18 & 2674,26 & 59,96 & 118,36 & 441,25 & 7146,8 & 7205,16 & 7265,12 & 4853,79 \\
\hline 13,950 & 1939,35 & 4173,05 & 295,91 & 2743,01 & 63,49 & 119,88 & 446,90 & 7275,5 & 7331,86 & 7395,34 & 4915,86 \\
\hline 14,725 & 1954,04 & 4204,67 & 298,15 & 2801,93 & 67,01 & 120,78 & 450,28 & 7371,8 & 7425,54 & 7492,55 & 4953,10 \\
\hline 15,500 & 1958,9384 & 4215,21 & 298,90 & 2851,01 & 70,54 & 121,09 & 451,41 & 7435,7 & 7486,20 & 7556,75 & 4966,52 \\
\hline
\end{tabular}

The diagram of the resulting moments of the prestressed concrete beams is shown below

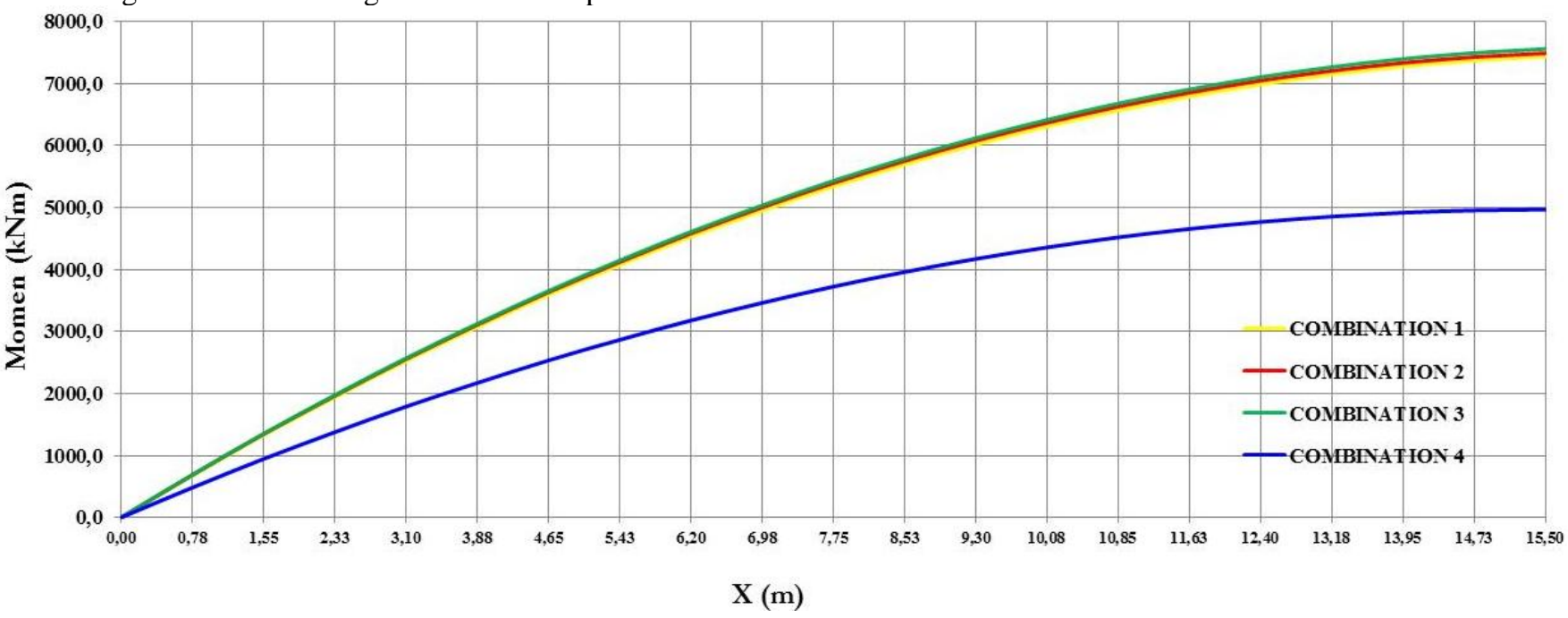

Figure 2 : Graph Showing the Moment Diagram (the Bending Momen Diagram) for Prestresses Beams

\section{Volume 5 Issue 4, April 2016}




\section{International Journal of Science and Research (IJSR) \\ ISSN (Online): 2319-7064 \\ Index Copernicus Value (2013): 6.14 | Impact Factor (2014): 5.611}

The calculations of the beams' shear force and load combinations are presented in Table 6 below.

Table 6 : Calculations of the beam's shear force and load combinations

\begin{tabular}{|c|c|c|c|c|c|c|c|c|c|c|c|}
\hline \multirow{3}{*}{$\begin{array}{c}\text { Distance } \\
\mathrm{X}\end{array}$} & \multicolumn{7}{|c|}{ Shear force of the pre stressed beams as result of loads } & \multirow{3}{*}{ 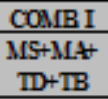 } & \multirow{3}{*}{$\begin{array}{c}\text { COMB II } \\
\text { MS+MA+ } \\
\text { TD+EIV }\end{array}$} & \multirow{2}{*}{$\frac{\operatorname{COM} \text { IR III }}{\text { MS+M. } \forall}$} & \multirow{2}{*}{$\frac{\cos \text { IB IV }}{\text { MS+MH }}$} \\
\hline & Weigh of & Omn Teight & Adititional Dead Loads & Lane Loads ' $\mathrm{D}$ " & Brale Forre & Wind Loads & Eartluqual: Loads & & & & \\
\hline & Beam & MS & MA & $\mathrm{ID}$ & IB & EW & \begin{tabular}{|l|} 
EQ \\
\end{tabular} & & & $\mathrm{TD}+\mathrm{TP}+\mathrm{EW}$ & EO \\
\hline $\mathrm{m}$ & $\mathrm{kN}$ & $\mathrm{kN}$ & $\mathrm{kN}$ & $\mathrm{kN}$ & $\mathrm{kN}$ & $\mathrm{hN}$ & $\mathrm{kN}$ & $\mathrm{kN}$ & $\mathrm{kN}$ & $\mathrm{kN}$ & $\mathrm{kN}$ \\
\hline 0,0 & 25277 & 543,90 & 38,57 & 310,89 & 4,55 & 15,62 & 58.25 & 897,9 & 908,98 & 913,53 & 640,71 \\
\hline 0,775 & 240,13 & 516,70 & 36,64 & 29820 & 4.55 & 14,84 & 55.33 & 856,1 & 86638 & 870,93 & 608,68 \\
\hline 1.550 & 227,49 & 489.51 & 34,71 & 285,50 & 4.55 & 14,06 & 52,42 & 8143 & 823,78 & 82833 & 576,64 \\
\hline 2325 & 214,85 & 462,31 & 3278 & 27281 & 4.55 & 13,28 & 49,51 & 7725 & 781,18 & 785,73 & 544,61 \\
\hline 3,100 & 202,21 & 435,12 & 30,85 & 260,11 & 4,55 & 1250 & 46,60 & 730,6 & 738,58 & 743,13 & 512,57 \\
\hline 3,875 & 189.57 & 407,92 & 2899 & 247,41 & 4.55 & 1172 & 43,68 & 688.8 & 695,98 & 700,53 & 480,53 \\
\hline 4,650 & 17694 & 380,73 & 27,00 & 234,72 & 4.55 & 10,94 & 40,77 & 647,0 & 653,38 & 657,93 & 448,50 \\
\hline 5,425 & 164,30 & 353,53 & 25,07 & 22202 & 4.55 & 10,16 & 37,86 & 605,2 & 610,78 & 615,33 & 41646 \\
\hline 6,200 & 151,66 & 326,34 & 23,14 & 209,33 & 4,55 & 9,37 & 34,95 & 563,4 & 568,18 & 57273 & 384,43 \\
\hline 6975 & 139,02 & 299,14 & 21,21 & 196,63 & 4,55 & 8.59 & 3204 & 521.5 & 525,58 & 530,13 & 352,39 \\
\hline 7,750 & 12638 & 271.95 & 19,28 & 183,94 & 4.55 & 7,81 & 29,12 & 479,7 & 48298 & 487,53 & 320,36 \\
\hline 8.525 & 113,74 & 244.75 & 17,36 & 171.24 & 4.55 & 7,03 & 2621 & 4379 & 440,38 & 444.93 & 288.32 \\
\hline 9,300 & 101,11 & 217,56 & 15,43 & 158,55 & 4,55 & 6.25 & 23,30 & 396,1 & 397,78 & 402,33 & 256,28 \\
\hline 10,075 & 88,47 & 190,36 & 13,50 & 145,85 & 4,55 & 5,47 & 20,39 & 354,3 & 355,18 & 359,73 & 224,25 \\
\hline 10,850 & 75,83 & 163,17 & 11.57 & 133,15 & 4.55 & 4,69 & 17,47 & 3124 & 31258 & 317,13 & 19221 \\
\hline 11,625 & 63,19 & 135,97 & 9.64 & 120,46 & 4.55 & 3.91 & 14.56 & 270,6 & 269,98 & 274,53 & 160,18 \\
\hline 12,400 & 50,55 & 108,78 & 7,71 & 107,76 & 4,55 & 3,12 & 1165 & 228,8 & 227,38 & 231,93 & 128,14 \\
\hline 13,175 & 37,91 & 81,58 & 5,79 & 95,07 & 4,55 & 234 & 874 & 187,0 & 184,78 & 189,33 & 96,11 \\
\hline 13,950 & 25,28 & 5439 & 3,86 & 82,37 & 4,55 & 1,56 & 5,82 & 145,2 & 14218 & 146,73 & 64,07 \\
\hline 14,725 & 12,64 & 27,19 & 193 & 69,68 & 4.55 & 0,78 & 291 & 103,3 & 99,58 & 104,13 & 3204 \\
\hline 15,500 & 0,00 & 0,00 & 0,00 & 5698 & 4.55 & 0,00 & 0,00 & 61.5 & 5698 & 61.53 & 0,00 \\
\hline
\end{tabular}

The diagram of the resulting shear force of the prestressed concrete beams is shown below

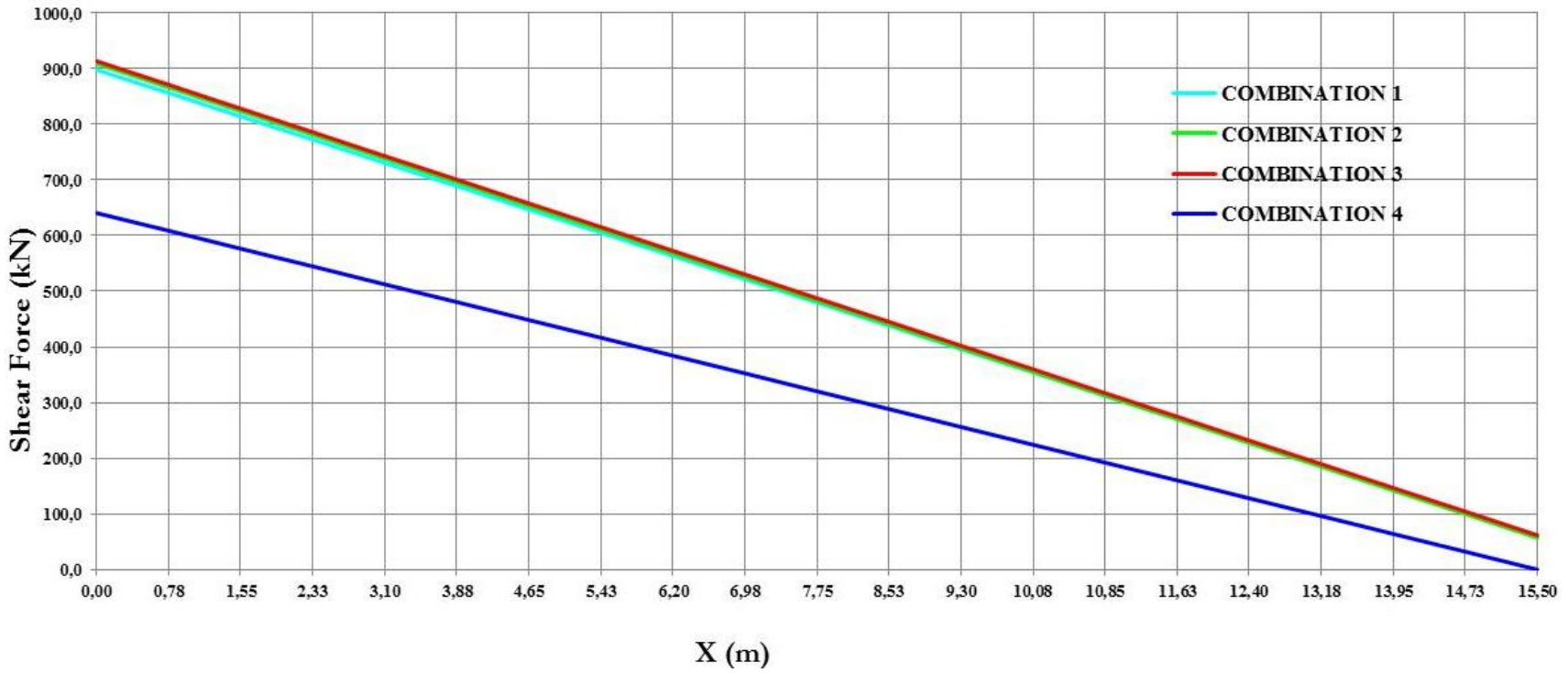

Figure 3: Graph Showing the Shear Force Diagram for Prestresses Beams

\section{Calculations of the Position, Eccentricity and Main Route of the Tendons}

\section{Position of the Tendons}

a) Position of the tendon in the middle span

A distance was taken from the beam base to the 1st tendon row axle $(\mathrm{a}=0.1 \mathrm{~m})$

The number of tendons of the 1st row ( nt1 = 3 tendons 19 strands 57 strands)

The number of tendons of the 2 nd row ( nt2 = 1 tendon 19 strands 19 strands)

nt $4=4$ tendons ns $=76$ strands

Eccentricity (es) $=0.620 \mathrm{~m}$

Beam Length $(\mathrm{L}) \quad=31 \mathrm{~m}$

Eccentricity (es) $=0.620$

Tendon route equation:

$\mathrm{Y}=4 \times \mathrm{f} \times\left(\mathrm{X} / \mathrm{L}^{2}\right) \times(\mathrm{L}-\mathrm{X})$

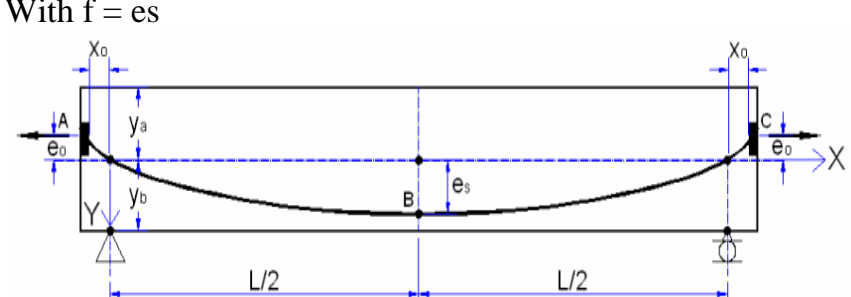

Figure 4 : The Main Route of Tendons

Using the cable route equation, the cable position coordinates for each absis value (distance unit) of the span length. 


\section{International Journal of Science and Research (IJSR) \\ ISSN (Online): 2319-7064 \\ Index Copernicus Value (2013): 6.14 | Impact Factor (2014): 5.611}

Table 7: Position of each tendon of prestressed beams

\begin{tabular}{|c|c|c|c|c|c|}
\hline \multirow{2}{*}{$\begin{array}{c}\text { Distance } \\
\mathbf{X} \\
(\mathrm{m})\end{array}$} & \multirow{2}{*}{$\begin{array}{c}\text { Trace } \\
\text { zo } \\
(\mathrm{m})\end{array}$} & \multicolumn{4}{|c|}{ Position of Each Cable } \\
\hline & & $\begin{array}{c}\mathbf{z 1} \\
(\mathrm{m})\end{array}$ & $\begin{array}{c}\mathbf{z 2} \\
(\mathrm{m})\end{array}$ & $\begin{array}{c}\mathbf{z 3} \\
(\mathrm{m})\end{array}$ & $\begin{array}{c}z^{4} \\
(\mathrm{~m})\end{array}$ \\
\hline 0 & 0,770 & 1,191 & 0,910 & 0,630 & 0,350 \\
\hline 0,775 & 0,710 & 1,104 & 0,831 & 0,578 & 0,326 \\
\hline 1,55 & Q,652 & 1,021 & 0,756 & 0,529 & 0,303 \\
\hline 2,325 & 0,598 & 0,943 & 0,685 & 0,483 & 0,281 \\
\hline 3,1 & 0,547 & 0,870 & 0,619 & 0,439 & 0,260 \\
\hline 3,875 & Q,499 & 0,801 & 0,556 & 0,398 & 0,241 \\
\hline 4,65 & Q,454 & 0,736 & 0,497 & 0,360 & 0,223 \\
\hline 5,425 & Q,412 & 0,676 & 0,442 & 0,324 & 0,206 \\
\hline 6,2 & 0,373 & 0,621 & 0,392 & 0,291 & 0,190 \\
\hline 6,975 & 0,338 & 0,569 & 0,345 & 0,260 & 0,176 \\
\hline 7,75 & 0,305 & 0,523 & 0,300 & 0,233 & 0,163 \\
\hline 8,525 & 0,276 & 0,480 & 0,264 & 0,207 & 0,151 \\
\hline 9,3 & 0,249 & 0,442 & 0,230 & 0,185 & 0,140 \\
\hline 10,075 & 0,226 & 0,409 & 0,199 & 0,165 & 0,131 \\
\hline 10,85 & 0,206 & 0,380 & 0,173 & 0,148 & 0,123 \\
\hline 11,625 & Q,189 & 0,356 & 0,151 & 0,133 & 0,116 \\
\hline 12,40 & Q,175 & 0,336 & 0,132 & 0,121 & 0,110 \\
\hline 13,175 & Q,164 & 0,320 & 0,118 & 0,112 & 0,106 \\
\hline 13,95 & Q,156 & 0,309 & 0,108 & 0,105 & 0,1025 \\
\hline 14,725 & Q,152 & 0,302 & 0,102 & 0,101 & 0,1006 \\
\hline 15,5 & 0,150 & 0,300 & 0,100 & 0,100 & 0,100 \\
\hline
\end{tabular}

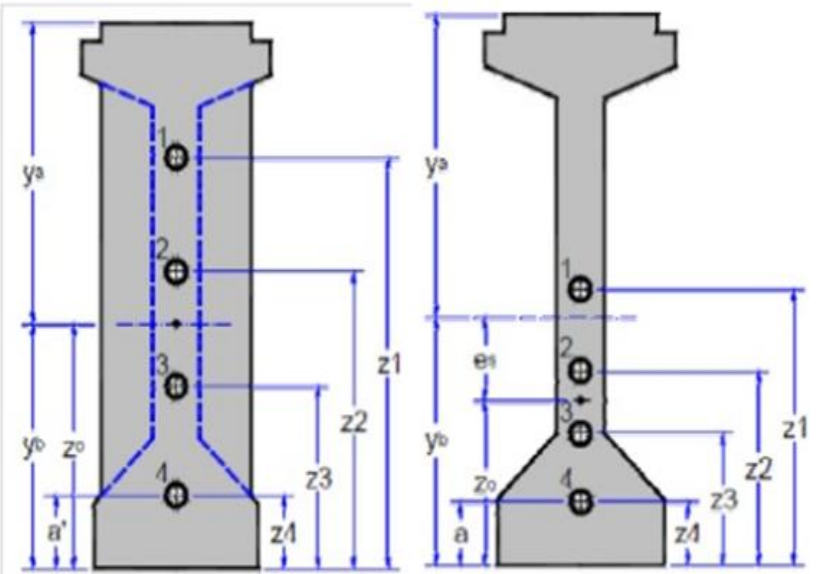

Figure 5: Tendon Positions in the Support and in the Middle Span

Tendon's position will vary at each distance. The tendon route is parabolic as shown in the figure below.

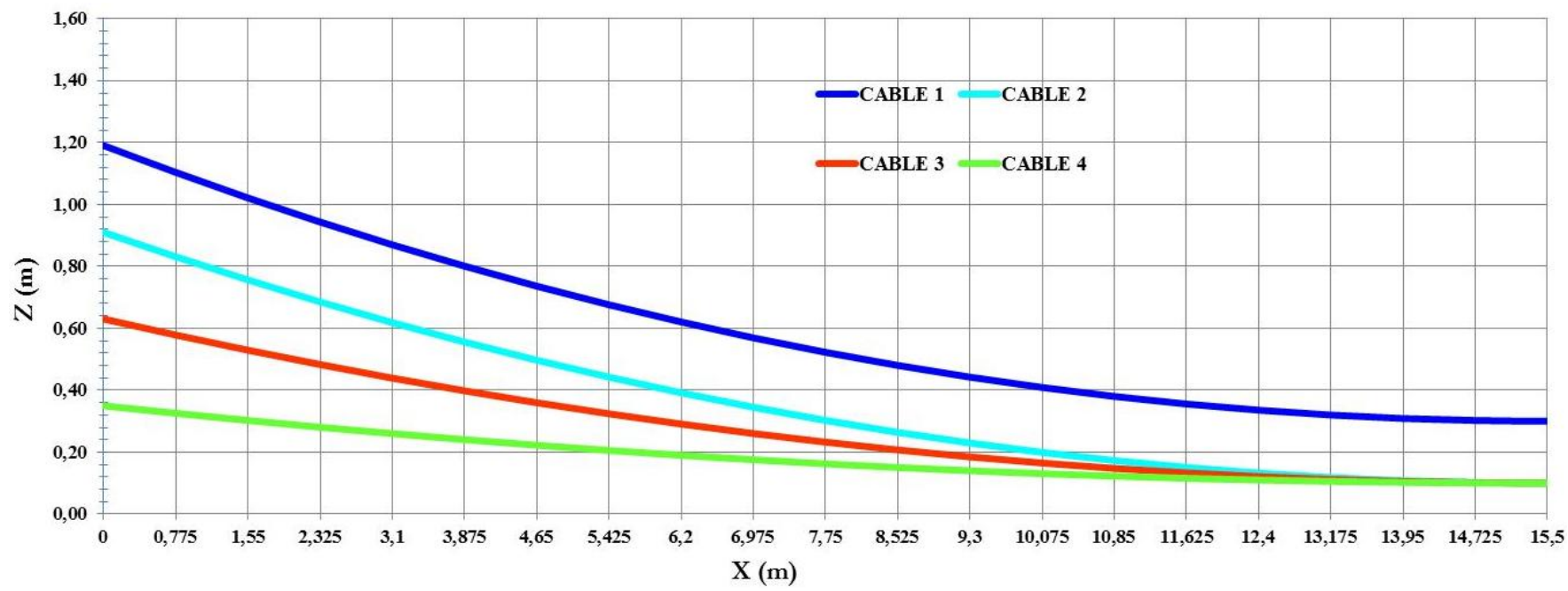

Figure 6 : The Trace of Each Tendon

\section{Loss of Prestress Forces}

Based on the calculations of the overall loss of prestress forces, the following loss of prestress forces in the table was generated.

Table 8: The Loss of each prestress forces

\begin{tabular}{|c|c|c|}
\hline Loss of Prestress Forces & Unit $(\mathrm{kPa})$ & $\begin{array}{c}\text { Percentage of the } \\
\text { Loss of Prestress } \\
\text { Forces (\%) }\end{array}$ \\
\hline Due to friction along tendons & 606,277 & $0.05 \%$ \\
\hline Due to transportation & $37,354,839$ & $2.87 \%$ \\
\hline $\begin{array}{l}\text { Due to elastic shortening of } \\
\text { concrete }\end{array}$ & $82,793,364$ & $6.36 \%$ \\
\hline Due to steel creep & $20,351,012$ & $1.56 \%$ \\
\hline Due to concrete shrinkage & $92,930,588$ & $7.14 \%$ \\
\hline Due to steel relaxation & $108,588,755$ & $8.34 \%$ \\
\hline \multicolumn{2}{|c|}{ Total Loss of Prestress Forces } & $26.32 \%$ \\
\hline
\end{tabular}

Fairly close to the initial estimation, i.e. the final loss of prestress forces $=30 \%$.

Kontrol tegangan pada tendon baja pasca tarik segera setelah penyaluran gaya prategang :

- The allowable stress of post-tensioning tendons: $0.7 \mathrm{x}$ fpu $=0.7 \times 1,860,000 \mathrm{kPa}=1,302,000 \mathrm{kPa}$

- The actual stress of the tendons of post-tensioned concrete:

$$
\begin{aligned}
& \mathrm{fp}=\left(\frac{\mathrm{P}_{\text {eef }}}{\text { At }}\right) \\
& =\left(\frac{6512,941 \mathrm{kN}}{0,007501 \mathrm{~m} 2}\right) \\
& =868.276,3632 \mathrm{kPa}<0,7 \mathrm{xfpu}
\end{aligned}
$$

$(1.302 .000 \mathrm{kPa})=$ Safe 


\section{International Journal of Science and Research (IJSR) \\ ISSN (Online): 2319-7064 \\ Index Copernicus Value (2013): 6.14 | Impact Factor (2014): 5.611}

As fp $<0.7 \mathrm{x}$ fpu, it can be concluded that the actual stress of the tendons of post-tensioned concrete is safe.

\section{Conclusion}

After undertaking the designing process, there are a number of things that can be concluded, namely:

1)For the planning of the Meureudu Bridge, tendons of cable strands with VSL (Vorspam System Losinger) standards, namely uncoated 7 Wire Super Strands ASTM A-416 grade 270 with the cross-section equal to $12.7 \mathrm{~mm}$ in width and the ultimate tensile stress by1,860 Mpa,were used. For the bridge's floor plates, $\mathrm{K}_{-300}$ concrete and $\mathrm{K}-{ }_{500}$ girders.

2)For prestressed beams with the middle span length by 31 meters using PCI Girder, the resulting dead loads of their own weight amounted to $16,308 \mathrm{kN}$, the weight of the floor plates amounted to $9.250 \mathrm{kN}$, the weight of dect slabs amounted to $2.118 \mathrm{kN} / \mathrm{m}$, the weight of the diaphragm amounted to $128.081 \mathrm{kN}$, the weight of asphalt layer + overlay amounted to $2.035 \mathrm{kN}$ and the weight of rain water amounted to $0.453 \mathrm{kN}$.

3)The resulting live loads consisted of the weight of evenly distributed lane loads by $8.855 \mathrm{kPa}$, the weight of line loads by $16.381 \mathrm{kN} / \mathrm{m}$, the weight of concentrated loads by $113.960 \mathrm{kN}$, the height of the brake force a beam received by $50 \mathrm{kN}$, the weight of the wind force by $1.008 \mathrm{kN} / \mathrm{m}$ and the weight of the earthquake loads by $3.5984 \mathrm{kN} / \mathrm{m}$.

4) The total loss of prestress forces was equal to $26.32 \%$ where the highest loss of prestress forces was resulted from steel relaxation (by 8.34\%) and the lowest one took place due to friction along the tendons $(0.05 \%)$.

5)The central route of the tendons of prestressed beams formed a parabolic shape with a changing tendon position depending on the route.

6)The greatest moment was equal to $7,556.75 \mathrm{kNm}$ obtained from a combination of its own weight, additional dead loads, lane loads, the brake force and wind loads. The greatest shearing force amounted to $913.53 \mathrm{kN}$.

7)The actual stress of the tendons of post-tensioned steel was equal to $868,276.3632 \mathrm{kPa}<$ the allowable stress of the post-tensioning tendons by $1,302,000 \mathrm{kPa}$

\section{References}

[1] BSNI, "Standar Imposition for Bridge", RSNI T-022005. Jakarta, 2005

[2] BSNI,"Concrete Struktural Design for Bridge”, SNI T-12-2004. Jakarta, 2004

[3] Ilham, Noer Muhammad, "Calculation of Prestressed Beams (PCI Girder), Selatan Tebing Rumbih (RAY 15) Bridges, Barito Kuala, South of Kalimantan", Available: http://www.mnoerilham.blogspot.com. [Accessed: Okt. 20, 2014]

[4] Lin, T. Y dan Burns, Ned. H, "Design of Prestressed Concrete Structures", Translation., Erlangga Press, Jakarta, 1993

[5] Mahulae, Cuknolan Beni, "Redesign Girder Beams of Balaraja Fly Over with PCI Girder", Faculty of Engineering, Sultan Ageng Tirtayasa University, 2011
[6] Nawy, Edward. G "Prestressed Concrete, A Fundamental Aproach", Translation, Erlangga Press, Jakarta, 2001

[7] Raju, N. Krishna, "Prestressed Concrete" Translation, Erlangga Press, Jakarta, 1988

[8] VSL, "VSL Your Solution Network", Available: http://www.vslin.com. [Accessed: Jan, 12, 2015] 